\title{
Shall I Approach Thee Through Improvised Play? Dramatising Poetry
}

\section{Stefanie Giebert}

\begin{abstract}
This article briefly describes reasons for dramatising poetry in the language classroom and then gives practical descriptions of how poetry can be taken 'from page to stage'. It focusses on the aspects content, form and context of poems and how they can be dramatised. A special focus is on working with Shakespearean sonnets but the ideas can be transferred to other types of poetry as well.
\end{abstract}

\section{Introduction}

Dramatising poetry in the language classroom - why and how? I first realised the dramatic potential of poetry when adapting Shakespeare's sonnets for a university drama club. Staging a full-length play based on a poetry-cycle is usually not possible in class, but individual poems are mostly short and thus well-suited for exploration during a class-period.

Despite this being a window of practice article, I will give a short overview of reasons for approaching poetry through drama before I describe concrete exercises. Moreover, besides ideas for dramatising Shakespearean sonnets, other authors' ideas about dramatising poetry in general will be included as well.

\subsection{Competences gained by working with poetry}

The articles that resulted from my database search on 'dramatising poetry' focus on two different target groups. Articles about poetry in L1 classrooms tend to focus on how students can be encouraged to appreciate poetry in itself (Feinberg 1979, Taylor 1994, Comeaux 1994) or on how certain types of poems can be taught (Rodberg \& Jennings 2007 or Newlin \& Bradford 2011 on sonnets). Texts about poetry in foreign/second language classrooms, however, often see poetry as a means to an end, a tool for improving learners' language proficiency (Tomlinson 1986, Gasparro \& Falletta 1994, Elting \& Firkins 2006, Hestnes 2009, Stöver-Blahak 2012). More concretely, the following benefits/uses of poetry in the EFL clasroom are listed:

Performing poems helps learners to practise pronunciation and intonation (Hestnes 2009, Elting \& Firkins 2006, Stöver-Blahak 2012). 
Performing poems helps learners acquire presentation competences, such as adequate body language and vocal expression (Stöver-Blahak 2012, Gasparro \& Falletta 1994).

Dramatising poetry helps learners gain confidence a nd fl uency in speaking (Gasparro \& Falletta 1994).

Working with poetry can teach learners how to infer meaning, because poetry often leaves things unsaid (Elting \& Firkins 2006).

Work in small performance groups can improve learners' team-work skills (Elting \& Firkins 2006).

A creative approach to the foreign language through poetry shows learners that this language is a "living, breathing, artistic material" (Elting \& Firkins 2006: 129).

Poetry serves as a stimulus for various communication activities (Tomlinson 1986: 33).

\subsection{Why perform poetry in class?}

The authors who advocate the use of poetry in the articles mentioned above mostly give two reasons for exploring and performing poetry. First of all, poems tend to be short and might thus be explored in their entirety within one class period and they might also appear more approachable to learners intimidated by long texts. In addition, poems are accessible through many channels, addressing the senses (Comeaux 1994: 78) and emotions (Tomlinson 1986). Tomlinson points out that these are reasons why poems can also be used in mixed-ability classrooms - they will appeal to learners in different ways on different levels (1986: 34). Secondly, despite their brevity, many poems are rich in meaning (Stöver-Blahak 2012: 73) and often express complex ideas in simple language, which, according to Hestnes (2009), may appeal especially to older and more advanced learners.

Why should poetry be performed? The first a rgument w ould be that, to be fully appreciated, poetry needs to be heard and spoken by the learners, not just read in silence. Secondly, dramatisation can make poetry more enjoyable. If students dislike poetry this is, in the opinion of the majority of authors cited here, mostly caused by an overly-analytic approach which gives students the impression that the only thing they can do with a poem is find its officially approved interpretation. Therefore, the authors conclude, it is necessary to show students that poetry can also be emotionally and physically experienced and enjoyed and interpreted creatively in many ways. But while most of the articles cited here recommend using poems in modern English, the following practical example focuses on a different type of poems, namely Shakespeare's sonnets. 


\section{Shall I approach thee through improvised play? Performing Shakespeare's sonnets}

Shakespeare's sonnets are often considered difficult e ven $\mathrm{f}$ or $\mathrm{n}$ ative speakers because of their complex and antiquated language. However, non-nativespeaking secondary school students of the higher grades (11 and upward in Germany) are often introduced to Shakespeare's dramas and poetry in their English lessons. So the following exercises can be used for this age-group or for university students of English literature.

\subsection{Focus on content - approaching the sonnets' topics}

Session 1 (45 min.)

1. Cognitive warm-up. Students approach a central topic from the poem - in the case of Shakespeare's sonnets for example 'love' or 'jealousy'. Students are asked to write down, as fast as they can, as many associations they can think of (at least five to ten) when they hear the word 'love' and to share their list with the group after two to three minutes of writing while the teacher collects the input on the blackboard/OHP.

2. Physical warm-up. To ease students into acting, they next have to get up, split into pairs and act out the minimalist dialogue of "I love you."/"I know." in at least three variations, working with different intonation and body language (e.g. fulfilled love, parting s cene, lover is r ejected, unfaithful partner begs for forgiveness, etc.). All pairs work simultaneously, with sidecoaching from the teacher if necessary.

3. Headlines. The teacher hands out 'scene headlines' and asks students in groups of three or four to freely improvise a short (ca. one minute) scene that fits the headline and after a preparation time of five minutes to perform it for the class. For a session on Shakespearean sonnets, those headings could for example be: 'I only did it to test you' (related to sonnet \#117), 'You look so sweet - but I think you're cheating' (\#93), 'Absence makes the heart grow fonder' (\#109), 'You are too good for me - goodbye!' (\#87), 'She's horrible. But I love her.' (\#137).

4. Translating into modern English / 'time traveller' exercise. Students could be told at this point that they have just acted out topics from Shakespeare's sonnets and that they will now look at one example in more detail, for instance sonnet \#117. Together the class translates the poem line by line into modern English (or into their native language). ${ }^{1}$ To put the translation to use, the students should then write a short script of how a dialogue between an Elizabethan and a modern person could sound. The principle here is that the Elizabethan uses the sonnet's lines as dialogue and the modern person interrupts and asks for clarification, thus difficult passages are paraphrased (for example sonnet \#117).

\footnotetext{
${ }^{1}$ For help with modern English prose translations, see for example: http://nfs . sparknotes.com/sonnets (Accessed 15 September 2015).
} 
A: John! Where have you been all this time!B: Accuse me thus: that I have scanted allWherein I should your great deserts repay - A: Wait a minute, what do you mean? B: I said that you are completely right if you blame me for forgetting to repay you for all the good you have done me - A: Well, I surely haven't seen much of you lately!B: Forgot upon your dearest love to callWhereto all bonds do tie me day by day - A: You forgot? Even though you feel bound to me so strongly? What else is there? (etc.)The session could then finish with a performance of the different versions of the script that the groups have come up with.

Session 2 (45 min.)

If there is time to continue exploring content, the second session could focus on free dramatic adaptations of several different sonnets. Shakespeare's sonnets, while linguistically challenging, are surprisingly suitable for dramatisation because of their dialogic nature. Even though there is mostly just one speaker, the lyrical I is in many sonnets clearly talking to (or about) someone. Some sonnets suitable for performance are for instance: 80 ('the tongue-tied lover'), 117 ('I only did it to test you'), 46/47 ('heart and eye at war'), 129 ('sick of sex'), 138 ('polite lies'), 144 ('love triangle').

When giving students selected sonnets to perform, the teacher will have to decide whether the literary innovation of the Shakespearean sonnet cycle (namely that the majority of sonnets are, contrary to Renaissance literary conventions, not addressed to a woman but to a man) will be revealed beforehand. It might actually be more interesting to let students try their hand at what probably most will interpret as a man speaking to a woman and only afterwards disclose that the speaker was addressing another man, possibly leading into a discussion of Elizabethan literary conventions and gender roles.

Also the teacher will have to decide how closely they want students to adhere to the original language of the sonnets. My advice would be to let students decide if they want to use the original lines, to freely paraphrase in modern English, or to mix original language and modern English. When dramatising a poem (of any kind) for performance, students should consider the following questions:

Who is speaking? Does the poem have a first person or third person point of view? How many speakers are there? Who is addressed? Is the addressee present in the scene? Are there any other characters in the scene?

Where is the poem set? Could this mean that there are additional (silent) characters in the scene, creating a background?

What is happening? Are any concrete actions described?

How do the characters feel? What is their relationship to each other?

How physical should the performance be? A choral reading might be the least intimidating choice. ${ }^{2}$ A full acting-out of the scene, possibly even with improvised text, seems most demanding (in terms of the acting and improvising skills required).

\footnotetext{
${ }^{2}$ Hadaway et al. list many variations (2011: 800-1) of choral readings.
} 
In addition, Newlin \& Bradford (2011) recommend the following guiding questions: What's the tone of the poem? How can you physicalize metaphor, simile, and personification? Where might you pause? Is there a key line? ${ }^{3}$

For a performance of Shakespeare's sonnets, here are a few more specific ideas:

The characters usually identified as the dramatis personae' of the sonnet-cycle are the speaker (a middle-aged poet), a good-looking, virtuous young man, a promiscuous 'dark lady' and a rival poet. Often personifications are used (time, death, the lover's heart, etc.) and could appear as characters in a dramatisation.

If the speaker is not talking to the young man, dark lady, or rival poet, who else could be listening to him disclosing his feelings? A friend, a family member, an acquaintance in a pub, a therapist?

Transfer to other 'genres' can work. To give a few examples, sonnet \#117 works well as a scene from a soap opera, \#46 as a courtroom scene, \#129 as a therapy session.

\subsection{Focus on form: visualising sonnet structures}

It seems that a poem's content is the most common focus when it comes to dramatising poetry. However, also the formal aspects of poems can be approached creatively and performatively. With regard to sonnets, students of English are usually introduced to two variants of the sonnet form - the so-called 'Italian' and 'English' sonnets. The following exercise can help to visualise the difference between the two, and make it more memorable.

1. The Italian sonnet consists of two parts, one of eight (octet) and one of six lines (sestet). Between the two there is often a break - a change in mood, a solution to an argument, a counter-thesis etc. - called volta or turn. Students are given an English example of an Italian sonnet (e.g. Wordsworth's "Milton" or Keats's "Chapman's Homer", Millay's "Only until this cigarette is ended") or an actual Italian sonnet in translation. Unknown words are clarified and the overall content explained, with a focus on the change between the two sections. It will then be the students' task to work out a visualisation of the poem's structure. (If time is short, the teacher might give direct instructions for an 'embodied reading'. Students form two groups, ideally made up of eight or, respectively, six students. They read their part of the sonnet aloud and include a physical turn before line nine. For example if the Millay sonnet is used, the two groups could at first face each other, after "And then adieu,-farewell!-" group 2 would do a quarter turn (now facing the audience), to indicate how the speaker turns away from her/his lover.)

2. The English sonnet consists of three four-line stanzas (quatrains) and one two-line-stanza (couplet). Often, the quatrains outline the argument of the sonnet while the final c o uplet $\mathrm{p} r$ ovides a $\mathrm{s} u$ mmary o $\mathrm{r} \mathrm{m}$ o ral o $\mathrm{r}$ a counterargument to the quatrains. The visualisation here will depend on the

\footnotetext{
${ }^{3}$ If students with lower language proficiency r e quire s t ep-by-step in structions on how to
} prepare reading a sonnet aloud they could follow the guidelines set out by Ehrlich (2002). 
content of the sonnet - for instance sonnet \#73 lends itself for the purpose because the three quatrains describe a decline (the year ends, the day ends, a fire i s d ying) $w$ hile the c ouplet p resents a $n$ e xhortation $t$ o $u$ se the remaining time. Students would read the entire poem, then split up into four groups (three quatrains, one couplet) and then receive the task of showing the idea of decline and the mood-change in the couplet e.g. through body positions (standing, sitting, lying down, with a contrasting stance in the couplet). To conclude this exercise, a reflection p hase c ould b e i ncluded s o s tudents have the chance to discuss or write down their impressions of this exercise - was it difficult t o c ome u p w ith a $\mathrm{n}$ id ea, h ow e ffective $\mathrm{d}$ o $\mathrm{t}$ hey $\mathrm{t}$ hink $\mathrm{t}$ his $\mathrm{w}$ as for remembering the sonnet structure, etc.

\subsection{Focus on context: staging a literary trial}

Even though most of the articles on performing poetry reviewed here leave out historical or biographical context, for teaching Shakespeare's sonnets this seems almost indispensable, given on-going debates in literary criticism about the autobiographical influences on the sonnets and their historical c o ntext. In order to explore context students could use longer forms of improvisations. For the topic 'breach of literary conventions' in Shakespeare's sonnets, the format of a trial works well, but will need at least a 90 minute session as it is a complex format. Students receive a list of roles: defendant (in our case the poet), plaintiff (in our case the dark lady, accusing the poet of libel and sodomy), attorneys of prosecution and defence, the jury and the judge (this could be the teacher-in-role, to help the jury with background information). They also receive a handout that describes the formalised steps of a trial, which they will need to follow in their improvisation, handouts with background information on gender roles and literary patronage, and the 'exhibits' - evidence brought by the prosecuting attorney to prove that the poet did wrong. In our case the exhibits were a traditional sonnet praising a woman's beauty by Edmund Spenser (sonnet \#15 from Amoretti) and Shakespeare's sonnet \#130, which describes the dark lady rather unfavourably and sonnet \#20 which praises the young man's beauty. Prosecution and defence present their arguments, the witnesses speak, and eventually the jury will have to debate which side they find more convincing.

The complex topics of literary patronage and literary conventions, gender roles and gender relations in Elizabethan England could for instance also be explored through the format of an interview or a talk-show featuring the poet and the other characters from the sonnets or the historical persons who might have been portrayed in the sonnets. ${ }^{4}$ Students might have difficulties comprehending Elizabethan concept of 'love' - the devaluation of women, the idealisation of male relationships, etc. - or might be unfamiliar with

\footnotetext{
${ }^{4}$ For some examples on how the historical context of German love poetry can be explored with dramatic conventions (interview with fictional e xpert, d ialogue b etween characters from two poems) see Horwitz 2011.
} 
the constraints that literary patronage put on writers but trying to change perspective and literally walking in someone else's shoes might, if not bring about complete understanding, at least trigger thought processes which can then lead to further discussion and exploration of these topics.

\section{Bibliography}

Comeaux, Patricia (1994): Performing Poetry: Centering the Language Arts Programme. In: Contemporary Education 65/2, 77-81

Ehrlich, Jeremy (2002): Page to Stage (A Lesson in Performance). In: The Folger Shakespeare Library. Available from:

http://pages.simonandschuster.com/ images/ ckfinder/ 26/ pdfs/ Folger\%20Curriculum\%20Guides/ sonnets.pdf (Accessed 15 September 2015)

Elting, Stephen; Firkins, Arthur (2006): Dramatising Poetry in the Second Language Classroom. In: English Teaching: Practice and Critique 5/3, 127-136. Available from:

http://education.waikato.ac.nz/research/files/etpc/2006v5n3art5.pdf (Accessed 15 September 2015)

Feinberg, Rose M. (1979): Poetry Theater-Integrating Drama and Poetry. Paper presented at the combined Annual Meeting of the Conference on English Education and the Secondary School English Conference (Pittsburgh, PA, March 15-18, 1979). ERIC Clearinghouse on Languages and Linguistics, Washington, DC.ED185573

Gasparro, Marie; Falletta, Bernadette (1994): Creating Drama with Poetry. Teaching English as a Second Language through Dramatization and Improvisation. ERIC Clearinghouse on Languages and Linguistics, Washington, DC. ED368214

Hadaway, L.; Vardell S.; Young, T. (2001): Scaffolding Oral Language Development through Poetry for Students Learning Language. In: The Reading Teacher 54/8, 796-806

Hestnes, Hæge (2009): Using Poetry in the ESL Classroom. Available from: http://www.fremmedspraksenteret.no/nor/fremmedspraksenteret/laringsressurser/leseveiledning-i-engelsk/text-types/poetry1\&PHPSESSID = aspae4mi2rqmu29uimccu9irh5 (Accessed 15 September 2015)

Newlin, Louisa; Bradford, Gigi (2011): Teaching Sonnets Unit Plan. In: The Folger Shakespeare Library. Available from: http://www.folger.edu/Content/Teach-and-Learn/TeachingResources/Teaching-Sonnets/ (Accessed 15 September 2015)

Rodberg, Simon; Jennings, Caleen S. (2007): Performing Sonnets. In: The Folger Shakespeare Library. Available from: 
http://www.folger.edu/eduLesPlanDtl.cfm?lpid=795 (Accessed 15 September 2015)

Stöver-Blahak, Anke (2012): Sprechen und Vortragenlernen im

Fremdsprachenunterricht. Interpretativ, kreativ und ganzheitlich mit Gedichten. Frankfurt: PeterLang

Taylor, Andrew (1994): 'On the pulse': Exploring Poetry through Drama. In: Children's Literature in Education 25/1, 17-28

Tomlinson, Brian (1986): Using Poetry with Mixed Ability Language Classes. In: ELT Journal 40/1, 33-41 